\title{
MOLECULAR TOOLS FOR SCREENING BIODIVERSITY
}




\section{JOIN US ON THE INTERNET VIA WWW, GOPHER, FTP OR EMAIL:}

WWW: http://Www.thomson.com

GOPHER: gopher.thomson.com

FTP:

ftp.thomson.com

A service of ITP

EMAIL: findit@kiosk.thomson.com 


\section{MOLECULAR TOOLS FOR SCREENING BIODIVERSITY}

\section{Plants and Animals}

Edited by

Angela Karp

IACR-Long Ashton Research Station,

Department of Agricultural Sciences

University of Bristol, UK

Peter G. Isaac

Agrogene SA

Moissy Cramayel, France

and

David S. Ingram

Regius Keeper of the Royal Botanic Garden Edinburgh, UK 
Published by Chapman \& Hall, an imprint of Thomson Science, 2-6 Boundary Row, London SE1 8HN, UK

Thomson Science, 2-6 Boundary Row, London SE1 8HN, UK

Thomson Science, 115 Fifth Avenue, New York, NY 10003, USA

Thomson Science, Suite 750, 400 Market Street, Philadelphia, PA 19106,

USA

Chapman \& Hall GmbH, Pappelallee 3, 69469 Weinheim, Germany

First edition 1998

(C) 1998 Chapman \& Hall

Softcover reprint of the hardcover 1st edition 1998

Thomson Science is a division of International Thomson Publishing I $\mathbf{T} \mathbf{P}^{\circledast}$

Typeset in 10/12 Palatino by Photoprint, Torquay, Devon

ISBN-13: 978-94-010-6496-5 e-ISBN-13: 978-94-009-0019-6

DOI: $10.1007 / 978-94-009-0019-6$

All rights reserved. No part of this publication may be reproduced, stored in a retrieval system or transmitted in any form or by any means, electronic, mechanical, photocopying, recording or otherwise, without the prior written permission of the publishers. Applications for permission should be addressed to the rights manager at the London address of the publisher.

The publisher makes no representation, express or implied, with regard to the accuracy of the information contained in this book and cannot accept any legal responsibility or liability for any errors or omissions that may be made.

A catalogue record for this book is available from the British Library

Library of Congress Catalog Card Number: 97-69525 
LIST OF CONTRIBUTORS

xiii

FOREWORD

xix

Mark Chase

PREFACE

xxi

Angela Karp, Peter G. Isaac and David S. Ingram

INTRODUCTION

xxiii

Etienne Magnien EU DGXII

$\begin{array}{llr}\text { PART ONE DNA EXTRACTION } & 1\end{array}$

1 DNA Extraction: widely applicable methods 3

1.1 Isolation of animal cellular total DNA 5

De-Xing Zhang and Godfrey M. Hewitt

$\begin{array}{lll}1.2 & \text { Plant total DNA extraction } & 10\end{array}$

Julia Rueda, Rosario Linacero and Ana M. Vázquez

1.3 Chloroplast DNA extraction procedure for species high in phenolics and polysaccharides

Roselyne Lumaret, Henri Michaud, Jean-Philippe Ripoll and Lamjed Toumi

1.4 Quantification of DNA

Rosario Linacero, Julia Rueda and Ana M. Vázquez

Box 1.1 Miniprep procedures for the isolation of plant DNA

Keith J. Edwards

2 DNA Extraction: methods for difficult species/tissues 25

2.1 Special DNA extraction methods for some animal species De-Xing Zhang and Godfrey M. Hewitt

(e.g. aphids, woodlice)

B: Extraction of total DNA from tissues or organisms with high nuclease activity

2.2 Methods for difficult plant species/tissues

Birgit Ziegenhagen and Florian Scholz

Box 2.1 DNA maxipreparations: A comparison of protocols for rapid extraction of good quality DNA from recalcitrant species Birgit Ziegenhagen and Florian Scholz 
vi Contents

3 Preserved specimens $\quad 39$

3.1 Isolation of DNA from preserved specimens $\quad 41$

De-Xing Zhang and Godfrey M. Hewitt

A: Chelex DNA extraction method for PCR-based analysis 42

B: Extraction of DNA from paraffin-embedded tissues for PCR 44 analysis

Box 3.1 Field collection: animals 46

De-Xing Zhang and Godfrey M. Hewitt

Box 3.2 Field collection: plants 49

Roger Hyam

4 DNA Extraction using anion-exchange chromatography and silica-gel based membranes

4.1 Isolation of nucleic acids using anion-exchange chromatography :

qiagen-tip based methods

Simone Gauch, Ralf Hermann, Petra Feuser, Uwe Oelmüller and Helge

Bastian

4.2 Isolation of nucleic acids using silica-gel based membranes: methods based on the use of QIAamp spin columns

Simone Gauch, Ralf Hermann, Petra Feuser, Uwe Oelmüller and Helge Bastian

A: DNA isolation from animal tissues using QIAamp spin columns

B: Isolation from plant tissue with DNeasy spin columns

Box 4.1 Isolation of total RNA from animal tissue using anion-exchange chromatography (qiagen-tips)

Simone Gauch, Ralf Hermann, Petra Feuser, Uwe Oelmüller and Helge Bastian

Box 4.2 Isolation of total RNA using silica-gel based membranes

Simone Gauch, Ralf Hermann, Petra Feuser, Uwe Oelmüller and Helge Bastian

PART TWO BASIC SCREENING METHODS

5 Isozymes

Gerhard Müller-Starck

6 RFLP analysis

Reinhold Brettschneider

Box 6.1 Nonradioactive probes

Peter G. Isaac 
8 Polymerase chain reaction $\quad 109$

$\begin{array}{lll}\text { 8.1 } & \text { Polymerase chain reaction } & 111\end{array}$

Rita Aert, Marleen Voet, Steven Van Campenhout, Jacqueline Vander

Stappen and Guido Volckaert

8.2 $\quad$ PCR sequencing

Guido Volckaert, Rita Aert, Marleen Voet, Steven Van Campenhout and Peter Verhasselt

Box 8.1 Routes to DNA sequencing

Guido Volckaert

8.3 Polymerase chain reaction-restriction fragment length polymorphism (PCR-RFLPs)

Keith J. Edwards

8.4 TGGE and DGGE

Michael Etscheid and Detlev Riesner

A: Temperature gradient gel electrophoresis

138

B: Denaturing gradient gel electrophoresis

141

Box 8.2 Theoretical aspects of thermal denaturation of nucleic acids

144

Michael Etscheid and Detlev Riesner

Box 8.3 Modifications for the improvement of TGGE and DGGE

Michael Etscheid and Detlev Riesner

Box 8.4 Temporal TGGE

Michael Etscheid and Detlev Riesner

Box 8.5 TGGE and SSCP

Michael Etscheid and Detlev Riesner

8.5 Single-strand conformation polymorphism (SSCP) analysis William.C. Jordan, Katherine Foley and Michael Bruford

8.6 A rapid screening procedure for detecting mtDNA haplotypes in humpback whales (Megaptera novaeangliae)

Anja H. Larsen, Pernille Feddersen and Per J. Palsbøll

Box 8.6 Modifications to SSCP analysis conditions

William C. Jordan, Katherine Foley and Michael Bruford

Box 8.7 Automation and the polymerase chain reaction

Richard G. Keightley

\section{RAPDs}

9.1 Randomly amplified polymorphic DNAs (RAPDs) 
viii Contents

Box 9.1 Reproducibility testing of RAPDs by a network of European

176

laboratories

C.J. Jones, K.J. Edwards, S. Castiglione, M.O. Winfield, F. Sala,

C. Van der Wiel, B.L. Vosman, M. Matthes, A. Daly, R. Brettschneider,

P. Bettini, M. Buiatti, E. Maestri, N. Marmiroli, R.L. Aert, G. Volckaert,

J. Rueda, A. Vazquez and A. Karp

10 AFLP

10.1 Amplified fragment length polymorphism (AFLP)

Michaela C. Matthes, Allan Daly and Keith J. Edwards

Box 10.1 Reproducibility testing of AFLPs by a network of European

laboratories

C.J. Jones, K.J. Edwards, S. Castiglione, M.O. Winfield, F. Sala,

C. Van der Wiel, B.L. Vosman, M. Matthes, A. Daly, R. Brettschneider,

E. Maestri, N. Marmiroli, R.L. Aert, G. Volckaert and A. Karp

11 SSRs

11.1 Genotyping with microsatellite markers

Claudio Ciofi, Stephan M. Funk, Trevor Coote, David J. Cheesman, Robert

L. Hammond, Ilik J. Saccheri and Michael W. Bruford

Box 11.1 Characteristics of microsatellites

202

Michael W. Bruford, Claudio Ciofi, Stephan M. Funk

11.2 PCR analysis of SSR polymorphisms in plants using agarose gels Michele Morgante, Antonella Pfeiffer, Irena Jurman, Gianpaolo Paglia and Angelo M. Oliveiri

Box 11.2 Fluorescent labelling of SSRs and automated detection

Michele Morgante, Antonella Pfeiffer, Irena Jurman, Gianpaolo Paglia and Angelo M. Oliveiri

Box 11.3 Reproducibility testing of SSRs by a network of European

laboratories

C.J. Jones, K.J. Edwards, C. Van der Wiel, B.L. Vosman, M. Matthes,

A. Daly, P. Bettini, M. Buiatti, E. Maestri, N. Marmiroli, J. Rueda,

A. Vazquez and A. Karp

PART THREE SOURCES OF PROBES AND PRIMERS

12 Probes

12.1 Cloning of random amplified polymorphic DNA (RAPD) to generate codominant genetic markers

Christoph Sperisen and Urs Büchler

12.2

cpDNA 
13.1 Nuclear DNA primers

13.2 Primers for animal mitochondrial DNA: the importance of speciesspecific primers

Per J. Pasbøll and Peter Arctander

13.3 cpDNA and mtDNA primers in plants

Rémy J. Petit, Brigitte Demesure and Sylvie Dumolin

Box 13.1 Variations on a theme

Ben Vosman

14 Ribosomal DNA probes and primers

Christian Schlötterer

15 Probes and primers for simple repeats

15.1 Isolation of microsatellite markers in animals

Robert L. Hammond, Ilik J. Saccheri, Claudio Ciofi, Trevor Coote, Stephan M. Funk, W. Owen McMillan, Michele K. Bayes, Emma Taylor and Michael W. Bruford

Box 15.1 VNTR probes

Michael W. Bruford

Box 15.2 Designing SSR primer pairs using MacVector Software

Michael W. Bruford, Claudio Ciofi, Stephan M. Funk, and Robert L.

Hammond

15.2 Isolation of microsatellite markers in plants

Michele Morgante, Anotella Pfeiffer, Irena Jurman, Gianpaolo Paglia and Angela M. Olivieri

16 Measures of polymorphism within and among populations

16.1 Definitions

Antoine Kremer, Rémy J. Petit and Odile Pons

16.2 Diversity and differentiation at the allelic level Antoine Kremer, Rémy J. Petit and Odile Pons

16.3 Diversity and differentiation at the nucleotide level 
$x$ Contents

17 Distance data 313

17.1 Measuring genetic distance $\quad 315$

Mark A. Beaumont, Kamal M. Ibrahim, Pierre Boursot and

Michael W. Bruford

18 Discrete data $\quad 327$

18.1 Binary data analysis $\quad 329$

Michael W. Bruford and Mark A. Beaumont

18.2 Reading DNA sequences 332 Gitte Petersen

18.3 Multiple alignment $\quad 334$ Jotun Hein

Box 18.1 Selected software packages for personal computers

Ole Seberg and Gitte Petersen

18.4 Constructing phylogenies from discrete data - parsimony methods 344 Ole Seberg and Gitte Petersen

18.5 Constructing phylogenies from discrete data - maximum likelihood Ole Seberg and Gitte Petersen

19 Molecules vs morphology Gitte Petersen and Ole Seberg

Box 19.1 Gene trees vs species trees

Gitte Petersen and Ole Seberg

PART FIVE CASE STUDIES

20 Accessions and collections 369

20.1 Comparison of molecular marker assays in inbreeding (barley) and outbreeding (potato) species

Dan Milbourne, Joanne Russell and Robbie Waugh

20.2 The use of molecular markers for the identification of tomato cultivars

Ben Vosman

20.3 Molecular analysis of variation in Lactuca

20.4 Evaluation of the AFLP and RAPD molecular marker technologies with regard to the genetic diversity of commercial wheat cultivars Allan Daly

Box 20.1 Screening germplasm collections

Gitte Petersen and Ole Seberg 
21 Populations $\quad 401$

21.1 PCR-RFLP analysis of chloroplast DNA of various gymnosperms: a 403 rapid tool for assessing genetic variation at the above-species level Birgit Ziegenhagen and Matthias Fladung

21.2 Analysis of hypervariable chloroplast microsatellites in Pinus

407 halepensis reveals a dramatic genetic bottleneck

Michele Morgante, Nicoletta Felice and Giovanni G. Vendramin

21.3 Genetic variation of mitochondrial DNA reveals subdivision of Norway spruce (Picea abies (L.) Karst.)

Christoph Sperisen, Urs Büchler and Gábor Mátyás

21.4 Diversity in insect species using DNA sequences

Godfrey Hewitt

21.5 The usefulness of parallel analysis of uni- and bi-parental markers: the North Atlantic humpback whale

Per J. Palsbøll, Phil J. Clapham, Hanne Jørgensen, Finn Larsen, David Mattila, Richard Sears, Johann Sigurjonsson and Oswaldo Vasquez

21.6 Partitioning of genetic diversity in the house mouse Pierre Boursot

22 Classification and phylogeny

22.1 Molecular studies on the phylogeny of the genus barley (Hordeum;

Poaceae)

Gitte Petersen and Ole Seberg

22.2 The genus Rhododendron: a case study to test the value of various molecular techniques as measures of biodiversity

David Chamberlain and Roger Hyam

22.3 RAPD fingerprinting as a tool for taxonomic studies in the genus Populus

Francesco Sala, Gejiao Wang, Stefano Castiglione and Stefano Bisoffi

23 Screening for 'useful variation'

23.1 Screening for 'useful variation' using RAPD markers

Robbie Waugh and Joanne Russell

23.2 Application of stress responsive genes RFLP analysis to the evaluation of genetic diversity in plants Nelson Marmiroli, Aliosha Malcevschi and Elena Maestri

23.3 Exploiting genome plasticity for the detection of hypervariable sequences

Marcello Buiatti and Paatrizia Bogani

Appendix Safety in the molecular laboratory

Peter G. Isaac and Keith J. Edwards

Index 


\section{CONTRIBUTORS}

\section{RITA AERT}

Laboratory of Gene Technology, Catholic University of Leuven, Willem de Croylaan 42, Leuven 3001, Belgium

\section{PETER ARCTANDER}

Department of Population Biology,

Zoological Institute University of

Copenhagen, Universitetesparken 15,

DK 2100 Copenhagen, Denmark

\section{HELGE BASTIAN}

QIAGEN GmbH, Max-Volmer-Straße 4, 40724 Hilden, Germany

MICHELE K. BAYES

Conservation Genetics Group, Institute of Zoology, Regent's Park, London, NW1 4RY, UK

\section{MARK A. BEAUMONT \\ Conservation Genetics Group, Institute of Zoology, Regent's Park, London, UK \\ PRISCILLA BETTINI \\ Universita degli Studi di Firenze, Dipartimento di Biologia Animale e Genetica, Via Romana, 17, 50125 Firenze, Italy}

\section{STEFANO BISOFFI}

Istituto Sperimentazione Pioppicoltura, P.O. Box 116, Via di Frassineto 35, I-15033 Casale Monferrato, Italy

\section{PATRIZIA BOGANI}

Universita degli Studi di Firenze, Dipartimento di Biologia Animale e Genetica, Via Romana, 17, 50125 Firenze, Italy

\section{PIERRE BOURSOT}

Laboratoire Genome et Populations, CNRS URP 9060, Université Montpellier II, 34095, Montpellier Cedex 5, France

\section{REINHOLD BRETTSCHNEIDER}

Universität Hamburg, Institut für

Allgemeine Botanik, Ohnhorststr. 18, 22609 Hamburg, Germany

MICHAEL W. BRUFORD

Conservation Genetics Group, Institute of Zoology, Regent's Park, London, NW1 4RY, UK

\section{URS BÜCHLER}

Eidgenössische Forschungsanstalt für Wald, Schnee und Landschaft, Zürcher Str. 111, CH-8903 Birmensdorf, Switzerland

\section{MARCELLO BUIATTI}

Universita degli Studi di Firenze, Dipartimento di Biologia Animale e Genetica, Via Romana, 17, 50125 Firenze, Italy

\section{KORNEL BURG}

Hauptabteilung Agrarforschung und

Biotechnologie, Bereich

Lebenswissenschaften, Österreichisches Forschungszentrum Seibersdorf G.m.b.H, A-2444 Seibersdorf, Austria

\section{STEPHANO CASTAGLIONE}

Dipartimento di Biologia, Universita di Milano, Via Celoria 26, I-20133 Milano, Italy

\section{DAVID CHAMBERLAIN}

Royal Botanic Garden Edinburgh, Inverleith Row, Edinburgh, EH3 5LR, UK 


\section{DAVID CHEESMAN}

Conservation Genetics Group, Institute of Zoology, Regent's Park, London

NW1 4RY, UK

CLAUDIO CIOFI

Conservation Genetics Group, Institute of Zoology, Regent's Park, London

NW1 4RY, UK

PHIL J. CLAPHAM

Center for Coastal Studies, Box 826,

Provincetown, MA 02657, USA

\section{TREVOR COOTE}

Conservation Genetics Group, Institute of Zoology, Regent's Park, London

NW1 4RY, UK

\section{ALLAN DALY}

Zeneca Seeds, Jealott's Hill Research Station, Bracknell, Berkshire, RG12 6EY, UK

\section{BRIGITTE DEMESURE}

INRA, Laboratoire de Génétique et Amélioration des Arbres, Forestiers; BP 45, F-33611 Gazinet Cedex, France

\section{SYLVIE DUMOLIN}

INRA, Laborataire de Genetique et Amelioration des Arbres, Forestiers; BP 45, F-33611 Gazinet Cedex, France

\section{KEITH J. EDWARDS}

IACR-Long Ashton Research Station, University of Bristol, Long Ashton, Bristol, BS18 7NZ, UK

\section{MICHAEL ETSCHEID}

Institut für Physikalische Biologie, HeinrichHeine-Universität Düsseldorf, Universitätsstraße 1, D-40225 Düsseldorf, Germany

\section{PERNILLE FEDDERSEN}

Department of Population Biology, Zoological Institute, University of Copenhagen, Universitetesparken 15, DK 2100 Copenhagen, Denmark
NICOLETTA FELICE

Universita degli Studi di Udine, Dipartimento di Produzione Vegetale e Technologie Agrarie,Via Fragagna, 209, I-33100 Udine, Italy

PETRA FEUSER

QIAGEN GmbH, Max-Volmer-Straße 4, 40724 Hilden, Germany

\section{MATTHIAS FLADUNG}

Bundesforschungsanstalt für Forst- und Holzwirtschaft Institut für Forstgenetik, Sieker Landstr. 2, D-2070 Großhansdorf 2, Germany

\section{SILVIA FLUCH}

Hauptabteilung Agrarforschung und Biotechnologie, Bereich

Lebenswissenschaften, Österreichisches Forschungszentrum Seibersdorf $\mathrm{GmbH}$, A-2444 Seibersdorf, Austria

\section{KATHERINE FOLEY}

Conservation Genetics Group, Institute of Zoology, Regent's Park, London,

NW1 4RY, UK

\section{STEPHAN M. FUNK}

School of Biological Sciences, University of Bristol, Bristol BS8 1UG, UK

SIMONE GAUCH

QIAGEN GmbH, Max-Volmer-Staße 4, 40724 Hilden, Germany

HARRIET A.A. GREEN

Conservation Genetics Group, Institute of Zoology, Regent's Park, London,

NW1 4RY, UK

\section{ROBERT L. HAMMOND}

King Khaled Wildlife Research Centre, National Commission for Wildlife Conservation and Development, Riyadh 11575, Saudi Arabia

JOTUN HEIN

Biologisk Institut, Bygn. 450, Aarhus

Universitet, DK-8000 Aarhus C, Denmark 
RALF HERMANN

QIAGEN GmbH, Max-Volmer-Straße 4, 40724 Hilden, Germany

GODFREY M. HEWITT

School of Biological Sciences, University of East Anglia, Norwich, NR4 7JJ, UK

\section{ROGER HYAM}

Royal Botanic Garden Edinburgh, Inverleith Row, Edinburgh, EH3 5LR, UK

KAMAL M. IBRAHIM

Biological Sciences, University of East

Anglia, Norwich, NR4 7JJ, UK

DAVID S. INGRAM

Royal Botanic Garden Edinburgh,

Edinburgh, EH3 5LR, UK

PETER G. ISSAC

Agrogene SA, 77550 Moissy-Cramayel,

France

\section{AHMED JAHOOR}

Technische Universität München, Lehrstuhl für Pflanzenbau und Pflanzenzuchtung, 85350 Freising-Weihenstephan, Germany

\section{CLIVE JONES}

IACR-Long Ashton Research Station, University of Bristol Long Ashton, Bristol, BS18 7NZ, UK

WILLIAM C. JORDAN

Conservation Genetics Group, Institute of Zoology, Regent's Park, London, NW1 4RY, UK

HANNE JØRGENSEN

Department of Population Biology,

Zoological Institute, University of Copenhagen, Universitetsparken 15, DK-2100 Copenhagen $\varnothing$, Denmark

IRENA JURMAN

Universita degli Studi di Udine, Dipartimento di Produzione Vegetale e Technologie Agrarie,Via Fragagna, 209, I-33100 Udine, Italy
ANGELA KARP

IACR-Long Ashton Research Station, University of Bristol, Long Ashton, Bristol, BS18 7NZ, UK

RICHARD G. KEIGHTLEY

Beckman Instruments (UK) Ltd, Oakley

Court, Kingsmead Business Park, London

Road, High Wycombe, Bucks, HP11 1JU, UK

ANTOINE KREMER

INRA Station de Recherches de Bordeaux-

Cestas, Laboratoire de Génétique et

Amélioration, BP 45 Gazinet, Pierroton,

F-33611 CESTAS, France

\section{ANJA H. LARSEN \\ Department of Population Biology, \\ Zoological Institute, University of \\ Copenhagen, Universitetesparken 15, \\ DK 2100 Copenhagen, Denmark}

\section{FINN LARSEN}

Greenland Institute of Natural Resources, Tagensvej 135, 1., DK-2200 Copenhagen N, Denmark

\section{ROSARIO LINACERO}

Departamento de Génetica, Facultad de Biología, Universidad Complutense, Ciudad Universitaria, 28040 Madrid, Spain

\section{ROSELYNE LUMARET}

Département de Biologie des Populations, Centre d'Ecologie Fonctionnelle et Evolutive (CEFE) Louis Emberger, CNRS, BP 5051, F-34033 Montpellier Cedex, France

W. YOWEN MCMILLAN

Conservation Genetics Group, Institute of Zoology, Regent's Park, London NW1 4RY, UK

\section{GORDON MACHRAY}

Scottish Crop Research Institute, Invergowrie, Dundee, DD2 5DA, UK 
ELENA MAESTRI

Dipartimento di Biologia Evolutiva, Ed Orto Botanico Facoltà di Scienze Matematiche/ Fisiche e Naturali, Università Degli Studi di Parma, Via delle Scienze, 43100 Parma, Italy

\section{ALIOSHA MALCEVSCHI}

Dipartimento di Biologia Evolutiva, Ed Orto Botanico Facoltà di Scienze Matematiche/ Fisiche e Naturali, Università Degli Studi di Parma, Via delle Scienze, 43100 Parma, Italy

\section{NELSON MARMIROLI}

Dipartimento di Biologia Evolutiva, Ed Orto Botanico Facoltà di Scienze Matematiche/ Fisiche e Naturali, Università Degli Studi di Parma, Via delle Scienze, 43100 Parma, Italy

\section{MICHAELA MATTHES}

IACR-Long Ashton Research Station, University of Bristol Long Ashton, Bristol, BS18 7NZ, UK

DAVID MATTILA

Center for Coastal Studies, Box 826, Provincetown, MA 02657, USA

\section{GÁBOR MÁTYÁS}

Eidgenössische Forschungsanstalt für Wald Schnee und Landschaft, Zürcher Str. 111, CH-8903 Birmensdorf, Switzerland

\section{HENRI MICHAUD}

Département de Biologie des Populations, Centre d'Ecologie Fonctionnelle et Evolutive (CEFE) Louis Emberger, CNRS, BP 5051, F-34033 Montpellier Cedex, France

\section{DAN MILBOURNE}

Scottish Crop Research Institute, Invergowrie, Dundee, DD2 5DA, UK

\section{MICHELE MORGANTE}

Universita degli Studi di Udine, Dipartimento di Produzione Vegetale e Technologie Agrarie,Via Fragagna, 209, I-33100 Udine, Italy

\section{GERHARD MÜLLER-STARCK}

LM-Universität München, Lehrbereich

Forstgenetik, Hohenbachernstr. 22,

D-85354 Freising Germany

\section{UWE OELMÜLLER}

QIAGEN GmbH, Max-Volmer-Straße 4, 40724 Hilden, Germany

\section{ANGELO M. OLIVIERI}

Universita degli Studi di Udine, Dipartimento di Produzione Vegetale e Technologie Agrarie,Via Fragagna, 209, I-33100 Udine, Italy

\section{GIANPAOLO PAGLIA}

Universita degli Studi di Udine, Dipartimento di Produzione Vegetale e Technologie Agrarie,Via Fragagna, 209, I-33100 Udine, Italy

\section{PER J. PALSBØLL}

Department of Population Biology, Zoological Institute, University of Copenhagen, Universitetesparken 15, DK 2100 Copenhagen, Denmark

\section{GITTE PETERSEN}

Botanisk Laboratorium, Gothersgade 140, DK-1123 København K, Denmark

RÉMY J. PETIT

INRA, Laboratoire de Génétique et Amélioration des Arbres, Forestiers; BP 45, F-33611 Gazinet Cedex, France

\section{ANTONELLA PFEIFFER}

Universita degli Studi di Udine, Dipartimento di Produzione Vegetale e Technologie Agrarie,Via Fragagna, 209, I-33100 Udine, Italy

\section{ODILE PONS}

Institut National de la Recherche Agronomique, Laboratoire de Biométrie, F-78352 Jouy-en-Josas Cedex, France 
DETLEV RIESNER

Institut für Physikalische Biologie, HeinrichHeine-Universität Düsseldorf,

Universitätsstraße 1, D-40225 Düsseldorf, Germany

JEAN-PHILIPPE RIPOLL

Département de Biologie des Populations,

Centre d'Ecologie Fonctionnelle et Evolutive (CEFE) Louis Emberger, CNRS, BP 5051, F-34033 Montpellier Cedex, France

JULIA RUEDA

Departamento de Génetica, Facultad de Biología, Universidad Complutense, Ciudad Universitaria, 28040 Madrid, Spain

JOANNE RUSSELL

Scottish Crop Research Institute, Invergowrie, Dundee, DD2 5DA, UK

\section{ILIK SACCHERI}

Department of Ecology \& Systematics, Division of Population Biology, University of Helsinki, 00014 Helsinki, Finland

\section{FRANCESCO SALA}

Dipartimento di Biologia, Universita di Milano, Via Celoria 26, I-20133 Milano, Italy

\section{CHRISTIAN SCHLÖTTERER}

Institut für Tierzucht und Genetik, Veterinaermedizinische Universitaet Wien, 1210 Wien, Austria

\section{FLORIAN SCHOLZ}

Bundesforschungsanstalt für Forst- und Holzwirtschaft Institut für Forstgenetik, Sieker Landstr. 2, D-2070 Großhansdorf 2, Germany

\section{RICHARD SEARS}

Mingan Island Cetacean Study, Inc., 285 Green St, Ste-Lambert, Qc J4P 1T3, Canada

\section{OLE SEBERG}

Botanisk Laboratorium, Gothersgade 140, DK-1123 Copenhagen K, Denmark

\section{JOHANN SIGURJONSSON}

Marine Research Institute, Skulagata 4, P.O. Box 1390, 121 Reykjavik, Iceland

\section{CHRISTOPH SPERISEN}

Eidgenössische Forschungsanstalt für Wald Schnee und Landschaft, Zürcher Str. 111, $\mathrm{CH}-8903$ Birmensdorf, Switzerland

\section{EMMA TAYLOR}

Conservation Genetics Group, Institute of Zoology, Regent's Park, London, NW1 4RY, UK

\section{LAMJED TOUMI}

Département de Biologie des Populations, Centre d'Ecologie Fonctionnelle et Evolutive (CEFE) Louis Emberger, CNRS, BP 5051, F-340033 Montpellier Cedex, France

\section{STEVEN VAN CAMPENHOUT}

Laboratory of Gene Technology, Catholic University of Leuven, Willem de Croylaan 42, Leuven 3001, Belgium

CLEMENS VAN DER WIEL CPRO - DLO, P.O. Box 16, 6700 AA Wageningen, Netherlands

\section{JACQUELINE VANDER STAPPEN}

Laboratory of Gene Technology, Catholic University of Leuven,Willem de Croylaan 42, Leuven 3001, Belgium
ANA M. VÁZQUEZ
Departamento de Génetica, Facultad de Biología, Universidad Complutense, Ciudad Universitaria, 28040 Madrid, Spain.
OSWALDO VASQUEZ
CIBIMA, Universidad Autonoma de Santo Domingo, Jonas Salk 55, Santa Domingo, Dominican Republic

\section{GIOVANNI G. VENDRAMIN}

Istituto Miglioramento Genetico Piante Forsetali, Via Atto Vannucci 13, I-50134 Firenze, Italy 
xviii Contributors

PETER VERHASSELT

Laboratory of Gene Technology, Catholic University of Leuven, Willem de Croylaan 42, Leuven 3001, Belgium

\section{MARLEEN VOET}

Laboratory of Gene Technology, Catholic University of Leuven, Willem de Croylaan 42, Leuven 3001, Belgium

\section{GUIDO VOLCKAERT}

Laboratory of Gene Technology, Catholic University of Leuven, Willem de Croylaan 42, Leuven 3001, Belgium

\section{BEN VOSMAN}

CPRO - DLO, P.O. Box 16, 6700 AA

Wageningen, Netherlands
GEJIAO WANG

Dipartimento di Biologia, Universita di Milano, Via Celoria 26, I-20133 Milano, Italy

ROBBIE WAUGH

Scottish Crop Research Institute, Invergowrie, Dundee, DD2 5DA, UK

MARK WINFIELD

The Botanic Garden, Cory Lodge, Bateman Street, Cambridge CB2 1JF, UK

DE-XING ZHANG

School of Biological Sciences, University of East Anglia, Norwich, NR4 7TJ, UK

BIRGIT ZIEGENHAGEN

Bundesforschungsanstalt für Forst- und Holzwirtschaft Institut für Forstgenetik, Sieker Landstr. 2, D-2070 Großhansdorf 2, Germany 


\title{
FOREWORD
}

\author{
Mark Chase
}

There are many literature resources available to molecular biologists wishing to assess genetic variation, but the myriad of techniques and approaches potentially available to the plant breeder and the evolutionary biologist is truly bewildering, and most have never been evaluated side-by-side on the same sets of samples.

Additionally, it is often not recognized that tools that are useful for breeders can often be adapted for use in evolutionary studies and vice versa, but this is generally the case. The borderline between population genetics and phylogenetics is vague and difficult to assess, and a combination of both types of tools is best when it is not clear with which area one is dealing. Furthermore, it is not now appropriate to use just one type of marker in any kind of study; most markers have the potential to misinform under certain conditions, so it is always wise to incorporate at least two different types of assessments into any project. This volume is designed to facilitate this sort of multiple approach and provides comparative data on most currently available methods so that researchers can more intelligently select those appropriate to their area of interest, regardless of whether it is in the realm of breeding or evolutionary biology.

Assessment of biodiversity has become such a commonly used term that what it actually means is not clear to many people. In some circles it has become synonymous with assessing the degree of genetic divergence among cultivars or strains, whereas to others it means evaluating the potential of naturally occurring variants for breeding programmes. To evolutionary biologists, it means assessing not only the within and between species variation but also phylogenetic relationships of species and other higher-level taxa, such as genera and families. Some workers would doubt the applicability of a generalized suite of techniques to all these types of studies, but I am convinced that this is indeed possible. Up to this point, there has been a lack of communication between people interested in these different areas but this volume presents techniques and approaches that are generally applicable. There are topics of importance in this volume for everyone, regardless of their research emphasis. The commercial breeder, the research geneticist and the evolutionary biologist will all find several chapters of relevance. The coverage of phylogenetic data and implications for population genetics of natural species are given the least attention, but there are good treatments of these areas by other volumes.

No other recent book has devoted so much time to problems with extracting DNA. The major crops and breeds are relatively easy to handle, but when dealing with a wider array of strains and species, one quickly encounters problem taxa. By accident, one of the selected systems to test the tools was Rhododendron (Ericaceae), and from personal experience a better target genus could not have been found.

Rhododendrons are amongst the most difficult plants with which to work, and thus they represent an almost perfect case study. If DNA can be extracted easily and reliably from these plants, then these methods are generally reliable for application across the diversity of plant species that exists in nature. 
No single book can expect to cover all areas in great depth, and this one is no exception. From my perspective, the single most important contribution of this volume is the extent to which it provides a measure of the reliability, reproducibility, and degree of ease of application that is found with the various techniques available. For example, everyone has suspected that RAPDs are subject to a greater than desirable degree of lack of reproducibility, but Chapter 9, Box 9.1 and Chapter 23.1 discuss this issue in depth. The same is true for the other various techniques: in addition to a description of how to carry out the necessary protocols there is a discussion of the practical matters that are as important as how to collect the data. There is nothing currently available that covers all these topics in such a critical and comparative manner. It is simply not a matter of following instructions; there are a multitude of other issues that need to be dealt with in practical and simple terms, and these topics are a major feature of this volume. Attention is paid as to whether a technique can provide assessments of heterozygosity and if the data are suitable for phylogenetic analysis as well as assessments of levels of variations within and between populations.

The last two issues that are important and that set this volume apart from others are its inclusion of non-radioactive and automated methods. The first is an obvious and desirable goal, but there has been a call for 'low-tech' methods by many workers so that costs of expensive automated machines could be avoided. There are indeed many 'low-tech' options discussed here, but it has also been recognized that if a technique cannot be automated it will limit the amount of information that can be collected and the number of samples that can be added to the data set. This ultimately is the benefit of automation: the ability to produce massive data sets and to use more than one approach. It has become increasingly clear to me over the last two years that automation is essential if we are to do our jobs and serve the interests of those who fund our research, and techniques that cannot be automated will not serve us well. 'Low-tech', regardless of lower costs, cannot compare with 'high-tech'. 
The conservation of natural genetic variation is important not only for ethical and aesthetic reasons but also to ensure that the earth's living resources may be used even more efficiently and sustainably in agriculture, forestry, food production and other industries. More needs to be known about the variation that already exists and how it can be conserved and accessed effectively. In the past 10 years there have been many advances in molecular biology that have provided a suite of powerful tools with enormous potential for the screening and evaluation of biodiversity. This volume was compiled in order to provide a comprehensive description and assessment of these tools. It includes a laboratory manual, in which detailed protocols for the techniques and analysis of the data they yield are described. In addition, a discussion is included of how the techniques can best be employed to tackle different diversity problems, using case studies of animals and plants as examples.

The book is aimed at investigators of all disciplines, with interests in the conservation, population biology, taxonomy, evolution, management, breeding and industrial application of plant and animal diversity. It is divided into five parts. In Part 1 there are four main chapters on DNA extraction, including: widely applicable methods; procedures for difficult species/ tissues; methods for preserved specimens; and DNA extraction using commercial kits. Each chapter is divided into separate sub-chapters covering plants and animals. In Part 2 protocols are given for the many different screening methods available, ranging from isozymes and hybridization-based procedures to a whole range of PCR-based methods. In both Parts 1 and 2 , all the contributors have introduced their subject with a review of the other methods available, and have presented not only the steps required for the procedures to work effectively, but also comments and tips that in their experience help to ensure success. The protocol chapters are supplemented by small boxes containing either additional information, or even additional methods, to ensure that as many features as possible are covered.

Part 3 of the book comprises chapters on sources of probes and primers and is a necessary complement to Part 2. The chapters vary in style depending on the subject matter. For example, detailed procedures are given for the isolation of microsatellite markers in plants and animals from enriched libraries (similar to Parts 1-2), whereas sources of nuclear, chloroplast and mitochondrial DNA are dealt with more descriptively. Part 4, which deals with data analysis, is largely composed of descriptive chapters which explain the different terminologies used and the methods of analysis that are essential for the effective and appropriate use of molecular data. The chapters are supplemented by boxes providing information of additional interest.

In the final Part case studies are of: (i) accessions and collections; (ii) populations; (iii) classification and phylogeny and; (iv) 'useful' variation. We did not restrict authors to a specific format. Some of the chapters, therefore, are short overviews (e.g. Chapter 21.4, Diversity in insect species using DNA sequences), whereas others describe individual studies (e.g. Chapter 21.5, The usefulness of parallel analysis of uni- and bi-parental markers: the North Atlantic humpback whale). All, however, have been chosen to reveal the usefulness of different markers. 
xxii Preface

The editors and contributors are all collaborators in an EU-funded project on 'Molecular Genetic Screening Tools', funded by the DGXII Biotechnology Unit. Exceptions are Jotun Hein, who kindly helped by writing the chapter on multiple alignment (18.3), and Mark Chase, who generously wrote the Foreword. We hope that our collective experience of these techniques, and their use in biodiversity studies, will be passed on through the book to all researchers who share an interest in plant and animal biodiversity.

Angela Karp

Peter G. Isaac

David S. Ingram 


\title{
INTRODUCTION
}

\author{
Dr Etienne Magnien
}

Modern biotechnology, that is the use of molecular and cellular methods to gain knowledge of and to master more precisely biological processes, dates back only two decades. With the number of applications steadily increasing, a purely technological change gradually becomes a societal change. Humankind can never again look at living things with the same eyes. The manufacturing processes of cells, tissues and organisms lend themselves to programmed design, also referred to as bioprocess engineering. The EU research programme refers to it as the cell factory concept. With an increasing role devolved to technicians in managing and exploiting the living world, many new questions on issues of safety for human health, sustainability, biomedical and environmental ethics, preservation of human dignity and animal welfare come to the fore. Society is increasingly interested in knowing what dictates whether a biological process, once in human hands, may go right or wrong, and how predictable the fate of this new relationship of man with living resources may turn out to be.

A widely shared concern seems to be the risk that biotechnology might contribute further to the uniformity of plant and animal populations because of the exclusive use of a few high performing varieties or animal races. Beside the fact that this is not a claim specific to biotechnology, but applicable to any straightforward intensification in agricultural production, the evidence today points to the contrary. Biotechnology now allows genes to circulate from species to species, making the total gene pool available for breeding and selection much wider than ever before. New genes have been introduced into crop plants to provide novel ways to resist pests and pathogens. Plants can even be engineered to produce new products such as haemoglobin, for human health care applications. Biotechnological techniques have also led to increased use of genetic resources through the provision of new genetic markers which give greater ability to locate genes more precisely, and to follow their inheritance during breeding cycles. The trend towards uniformity or diversity is not imposed by the technology, it results from the value of rare products amenable to a breeding scheme and the relative abundance and diversity of such products in the pool. With biotechnology, numerous products of remote origins will become accessible and may end up in valuable new genetic combinations.

The difference is made by the attractiveness of the genetic attributes which could be picked up more widely, and not by the technology to bring about such attributes.

This is a reassuring principle, because the putatively endangered biodiversity, challenged by mechanization, deforestation, urbanization, and so on, will find an ally in technology whose side effect is to increase access to the global gene pool and which makes genetic innovation more directly dependent upon the range of diversity that can be made available.

Hence, the timeliness of the EU programme supporting research on molecular tools to characterize genetic diversity, part of Biotechnology R\&D (1994-1998). Even before biotechnology starts bearing fruits, this molecular screening will make it possible to describe the extent of diversity in a species from any given habitat, population or inside collections. Traits will be traced or predicted. Gene frequencies will be monitored. Kinship will be measured. In 
other words, genetic fingerprinting and other tools derived from it will be developed for a wide range of applications until genetic monitoring is a reality for the conservation, management and utilization of genetic resources.

It is to the credit of the members of the EU Molecular Screening Tools project, coordinated overall by A. Karp, that they shared this belief and made rapid progress to deliver screening methods usable across many different species in various operational conditions. The utility of the techniques was confirmed by the setting-up of a platform of users in 1996: the Biotechnology for Biodiversity Platform. New jobs are created to satisfy the demand in standardized analytical kits for large-scale applications. An ultimate though vital step is now being made in the compilation of the methods developed so far for the benefit of breeders, curators, conservationists, taxonomists and others. In this way, scientists under contract with the EU are disseminating their technological advances for the widest possible social benefit. 